\title{
Article \\ Experimental Analysis and Mathematical Model of FSW Parameter Effects on the Corrosion Rate of Al 6061-T6-Cu C11000 Joints
}

\author{
Félix Alan Montes-González ${ }^{1}$ (D), Nelly Abigaíl Rodríguez-Rosales ${ }^{1}{ }^{*}$, Juan Carlos Ortiz-Cuellar ${ }^{2}$, \\ Carlos Rodrigo Muñiz-Valdez ${ }^{2}$, Josué Gómez-Casas ${ }^{2}$, Jesús Salvador Galindo-Valdés ${ }^{2}$ and Oziel Gómez-Casas ${ }^{2}$ \\ 1 Departamento de Metal Mecánica, Tecnológico Nacional de México/I.T. Saltillo, \\ 25280 Saltillo, Coahuila, Mexico; felix.montes@uadec.edu.m \\ 2 Facultad de Ingeniería, Universidad Autónoma de Coahuila, 25350 Arteaga, Coahuila, Mexico; \\ carlosortiz@uadec.edu.mx (J.C.O.-C.); rodrigo.muniz@uadec.edu.mx (C.R.M.-V.); \\ jogomezc@uadec.edu.mx (J.G.-C.); s_galindo@uadec.edu.mx (J.S.G.-V.); ogomez@uadec.edu.mx (O.G.-C.) \\ * Correspondence: nrosales@itsaltillo.edu.mx
}

Citation: Montes-González, F.A.; Rodríguez-Rosales, N.A.; Ortiz-Cuellar, J.C.; Muñiz-Valdez, C.R.; Gómez-Casas, J.;

Galindo-Valdés, J.S.; Gómez-Casas, O.

Experimental Analysis and

Mathematical Model of FSW Parameter Effects on the Corrosion Rate of Al 6061-T6-Cu C11000 Joints. Crystals 2021, 11, 294. https:// doi.org/10.3390/cryst11030294

Academic Editor: Bolv Xiao

Received: 27 January 2021

Accepted: 8 March 2021

Published: 16 March 2021

Publisher's Note: MDPI stays neutral with regard to jurisdictional claims in published maps and institutional affiliations.

Copyright: (c) 2021 by the authors. Licensee MDPI, Basel, Switzerland. This article is an open access article distributed under the terms and conditions of the Creative Commons Attribution (CC BY) license (https:// creativecommons.org/licenses/by/ $4.0 /)$
Abstract: Friction stir welding is characterized as an ecological and low-cost process in comparison to traditional welding techniques, and due to its application in the solid state, it is a feasible option for joining similar and/or dissimilar materials. The present investigation seeks to determine the effect of friction stir welding's parameters on the corrosion resistance of an Al 6061-T6-Cu C11000 dissimilar joint, with mathematical analysis to validate the results. After the welding process, the samples were exposed to a $\mathrm{NaCl}$ solution in an electrochemical cell to determine the corrosion rate via potentiodynamic tests. Microstructural characterization revealed a laminar structure, composed of aluminum and copper, as well as copper particles and the formation of intermetallic compounds distributed in the weld zone. The potentiodynamic tests showed that the corrosion rate increased with the rotational and traverse speeds. The mathematical model quantifies the relationship between corrosion rate and rotational and traverse speeds.

Keywords: friction stir welding; aluminum; copper; corrosion resistance; mathematical model; correlation

\section{Introduction}

Friction stir welding (FSW) is a solid-state method of joining similar or dissimilar plates, which only uses a non-consumable rotary tool to produce the joint without the need for a filling material. The rotary tool is applied with sufficient downward force to maintain significant contact between the shoulder surface of the rotary tool and the workpieces, thus enacting the weld. When the pin tool makes contact with the workpieces along the weld line, the friction between the tool shoulder and the upper surfaces of the workpieces heats them up and moving the softened material around the tool pin generates the severe plastic deformation of the workpieces. The tool shoulder then restricts further penetration while expanding the hot zone, and thus creates the joint in the workpieces $[1,2]$. Compared to conventional welding techniques, FSW generates fewer defects in the weld zone, such as porosity, hot cracking, inclusions, etc., with low energy consumption, thus offering an ecological and economical option [3-6]. In addition, FSW has relevant industrial applications in the automotive, aerospace, railway, nuclear and chemical industries $[1,7,8]$. FSW has become one of the most successful methods of joining different materials, such as Al-Mg [9,10], Al-Ti [11,12], Al-Fe [13-15] and Al-Cu [2,4,5,7,16-19], wherein physical, chemical, and thermal factors greatly influence the heat generated during the process, as well as the flow of materials, the microstructures, and the final mechanical properties of the weld. 
Nevertheless, due to the differences in metallurgical and mechanical properties between copper and aluminum, their joining represents a challenge; however, such joints have recently been achieved via FSW, and this is now one of the main techniques under investigation in this area [16-27]. The main applications of $\mathrm{Al}-\mathrm{Cu}$ joints are as conductors in transformers, electrical connectors, busbars, heat exchanges, etc., combining the electrical conduction capacity of copper and the heat dissipation capacity of aluminum $[19,20,28]$. The selection of the appropriate welding parameters, such as the rotational speed, traverse speed and tool plunge depth, plays an important role in these investigations $[4,5,7,24,29]$. Previous studies undertaken on these alloys have achieved excellent quality welds with good mechanical properties $[1,4,22,25,30,31]$; however, corrosion resistance has barely been studied $[27,29,32-34]$.

The main objective of this work is to determine the effect of the FSW's parameters on the corrosion resistance of the weld zone in $\mathrm{Al} 6061-\mathrm{T} 6-\mathrm{Cu}$ C11000 joints via potentiodynamic test with statistical analysis. The welding parameters, such as the rotational and traverse speeds, are varied to analyze how the corrosion rate is affected. The development of a mathematical model allows for the optimization of the FSW process without resorting to excessive experimentation and parametrization to improve the welding product's quality. In addition, the mathematical model allows one to predict and simulate the corrosion resistance achieved with different welding parameters of interest. Several investigations have developed mathematical models for the FSW process in order to estimate the behavior of some variables, such as thermal gradients, stresses, strain rates, torque, temperature, defects in the weld zone, hardness, etc. [35-38]. Nevertheless, as regards the analysis and construction of a mathematical model, only a few investigations have been carried out that provide estimations of corrosion resistance due to weight loss and pitting [32].

\section{Materials and Methods}

This research is an extension of the work done by Garcia [16], who investigated the effects of the FSW's parameters on the microstructural and electrical properties of $\mathrm{Al}$ 6061T6-Cu C11000 plate joints. The welding parameters, as well as the dimensions and chemical compositions of each alloy, were kept the same. The Al 6061-T6 plate was placed on the advancing side and the $\mathrm{Cu} \mathrm{C} 11000$ plate on the retreating side, with a $2 \mathrm{~mm}$ displacement of the rotary tool towards the aluminum's side. We used a heat-treated D2 steel rotary tool with a $4.5: 1$ shoulder/pin diameter ratio and $2.8 \mathrm{~mm}$ long pin. Figure 1 shows a schematic of the FSW configuration used in the present investigation. Counterclockwise rotational speeds of 1000, 1150, and $1300 \mathrm{rpm}$, and traverse speeds of 20, 40, and $60 \mathrm{~mm} / \mathrm{min}$, were used. The plates' dimensions were $100 \times 50.8 \times 3 \mathrm{~mm}$, and a two-combination set of each of the welding parameters was selected. Table 1 presents the chemical composition of both materials according to the manufacturer's data.

Table 1. Chemical composition of base materials (wt.\%).

\begin{tabular}{cccccccc}
\hline Element & Al & Cu & Fe & Cr & Mg & Zn & Si \\
\hline $\begin{array}{c}\text { Al } \\
6061-T 6\end{array}$ & Bal. & 0.38 & 0.57 & 0.33 & 1.12 & 0.25 & 0.53 \\
$\begin{array}{c}\text { Cu } \\
\mathrm{C} 11000\end{array}$ & - & 99.9 & - & - & - & - & - \\
\hline
\end{tabular}

The selection of the parameters employed in the FSW was based mainly on experience and the reported experimental results. Different investigations in which Al 6061 and commercially pure Cu were joined [16-19,25,39] obtained quality joints. The plate thickness, the welding parameters and the configuration used vary with a traverse speed from 30 to $100 \mathrm{~mm} / \mathrm{min}$ and a rotational speed from 710 to $1500 \mathrm{rpm}$. The configurations are also dependent on the insertion of the tool into the copper side vs. the aluminum side, and the angle of pin insertion. All these factors have effects on the mechanical properties of the joint, obtaining maximum strengths ranging from 85 to $133 \mathrm{MPa}$ with hardness values of 
120-188 HV. However, these investigations concluded that the best properties are obtained with intermediate rotational speeds and low traverse speed, as control of the heat input and a uniform material flow are essential to obtaining solid joints.

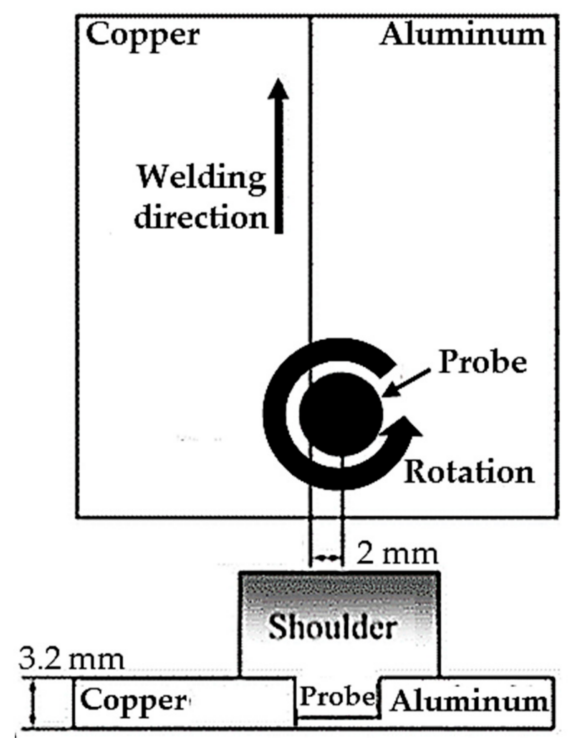

Figure 1. Schematic diagram of the friction stir welding (FSW) configuration.

Heat input is proportional to the increase in rotational speed, which causes undesirable metallurgical transformations, such as precipitation and the thickening of intermetallic compounds (IMCs) and grain growths, and these will degrade the strength of the joint. Otherwise, the low rotational speed will not generate enough heat to ensure adequate plasticization, which leads to the lower strength of the joint. The traverse speed affects the heat distribution generated during welding, and it reduces the heat input. This disrupts the plasticized material flow, giving rise to cavities and tunnels in the weld zone since there is insufficient material being deposited to fill the empty space [40].

As such, this research focuses on the range of rotational speeds from 1000 to $1300 \mathrm{rpm}$ and traverse speeds from 20 to $60 \mathrm{~mm} / \mathrm{min}$. In order to avoid compromising the mechanical properties and determine the corrosion rate, we also attempt to reduce the uncertainty surrounding the use of these unions under corrosive media. The different combinations of the welding parameters are presented in Table 2.

Table 2. Different combinations of FSW parameters applied to Al 6061-T6-Cu C11000 joints.

\begin{tabular}{|c|c|c|}
\hline Sample & Rotational Speed (rpm) & Traverse Speed $(\mathrm{mm} / \mathrm{min})$ \\
\hline S1000-20 & \multirow{3}{*}{1000} & 20 \\
\hline S1000-40 & & 40 \\
\hline S1000-60 & & 60 \\
\hline S1150-20 & \multirow{3}{*}{1150} & 20 \\
\hline S1150-40 & & 40 \\
\hline S1150-60 & & 60 \\
\hline S1300-20 & \multirow{3}{*}{1300} & 20 \\
\hline $\mathrm{S} 1300-40$ & & 40 \\
\hline S1300-60 & & 60 \\
\hline
\end{tabular}

The initial and final parts of the weld samples were neglected due to the hole left by the rotary tool on the upper surface at the end of welding. This left only the central 
part of the joined plates, of approximately $60 \mathrm{~mm}$ in length, from which 3 samples were taken for characterization and corrosion tests. The upper surface of each sample was metallographically prepared before corrosion testing. The samples were gradually ground using $\operatorname{SiC}$ paper $(80,220,320,400,600,800,1200$ and 2400) with water as a lubricant. Then, the samples were polished with 1 and $0.3 \mu \mathrm{m} \mathrm{Al} \mathrm{O}_{2} \mathrm{O}_{3}$ suspensions, and then with a $0.25 \mu \mathrm{m}$ diamond paste to obtain a mirror finish. Finally, the samples were rinsed with water and alcohol before being tested.

The corrosion rate was evaluated via potentiodynamic tests restricted to the weld zone; three samples for every welding condition were tested to gain the average corrosion rate in mils per year (mpy) penetration. The experiments were carried out in an electrochemical cell connected to a Gamry potentiostat/galvanostat/zero-resistance ammeter interface 1000A (Philadelphia, PA, USA). A solution of 3.5\% NaCl at room temperature was used as the electrolyte; the counter electrode and reference electrode were provided by platinum mesh and a $\mathrm{Ag} / \mathrm{AgCl}$ electrode, respectively, with a $1 \mathrm{~cm}^{2}$ area of exhibition. The scan rate was $0.167 \mathrm{mV} / \mathrm{s}$ from $-150 \mathrm{mV}$ to $+1500 \mathrm{mV}$ vs. $E_{\text {corr }}$. Before the corrosion tests commenced, each sample was cathodically polarized at $-1000 \mathrm{mV}$ for $5 \mathrm{~min}$, followed by stabilization for $60 \mathrm{~min}$ [41]. After the corrosion tests, the samples were observed via scanning electron microscopy (SEM; JEOL USA, Inc., Pleasanton, CA, USA). Garcia [16] performed a semiquantitative analysis via energy-dispersive X-ray spectroscopy (EDS; JEOL USA, Inc., Pleasanton, CA, USA) on the particles found in the weld zone, in order to identify the IMCs present; this analysis was, therefore, omitted from this investigation.

\section{Results and Discussion}

\subsection{Effect of Welding Parameters on Upper Surface of Each Sample}

Figure 2 shows the Al-Cu joints obtained under different FSW conditions. The presence of defects, such as burrs and small cavities, was observed in the upper surfaces of most samples. In a cross-sectional weld zone, it was found that reducing the traverse speed with a constant rotational speed raises the heat input into the weld zone, generating more IMCs [16,38,41,42]. With greater heat input, the softened material plastically deforms and a turbulent material flow arises in the weld zone. As a result, greater amounts of intermetallic compounds develop, while $\mathrm{Cu}$ particles are variously distributed into the weld zone. These IMCs are very hard and susceptible to crack-formation, and thus reduce the joint strength [38]. The heat input is inversely proportional to the traverse speed, i.e., a high traverse speed produces insufficient heat input, giving rise to an incomplete welded joint interface [41]. The lower heat input at very high traverse speeds causes the inadequate mixing of $\mathrm{Al}-\mathrm{Cu}$ materials, giving rise to defects such as voids. Insufficient flow of material at higher traverse speed results in the formation of cavities or tunneling defect inside the joints. However, when decreasing the traverse speed, the weld zone temperature rises, which consequentially reduces the flow stress. This produces a better plastic flow of materials, and less chance of a cavity defect [43]. At higher rotational speeds the heat input increases, and vice versa. Therefore, a combination of a high rotational speed $(1300 \mathrm{rpm})$ and a high traverse speed $(60 \mathrm{~mm} / \mathrm{min})$ produces enough heat to achieve a defect-free surface.

Figure 3 presents an upper surface macro-section of each sample after metallographic preparation, in order to observe the pattern flow generated during FSW. It shows the advanced side of the aluminum in a dark tone and the retreating side of the copper in a light tone, while at the welded area, a mixture of $\mathrm{Al}-\mathrm{Cu}$ and the presence of copper particles can be seen. The action of the shoulder tool, the heat input generated by the rotary tool, the formation of intermetallic compounds and the scattering of copper particles into the aluminum side can all be seen, with a different pattern flow for each sample. By EDS and $X$-ray diffraction, Garcia [16] identified the presence of intermetallic compounds, such as $\mathrm{Al}_{2} \mathrm{Cu}, \mathrm{Al}_{4} \mathrm{Cu}_{9}, \mathrm{AlCu}_{3}$ and $\mathrm{AlCu}$, as an inevitability. 


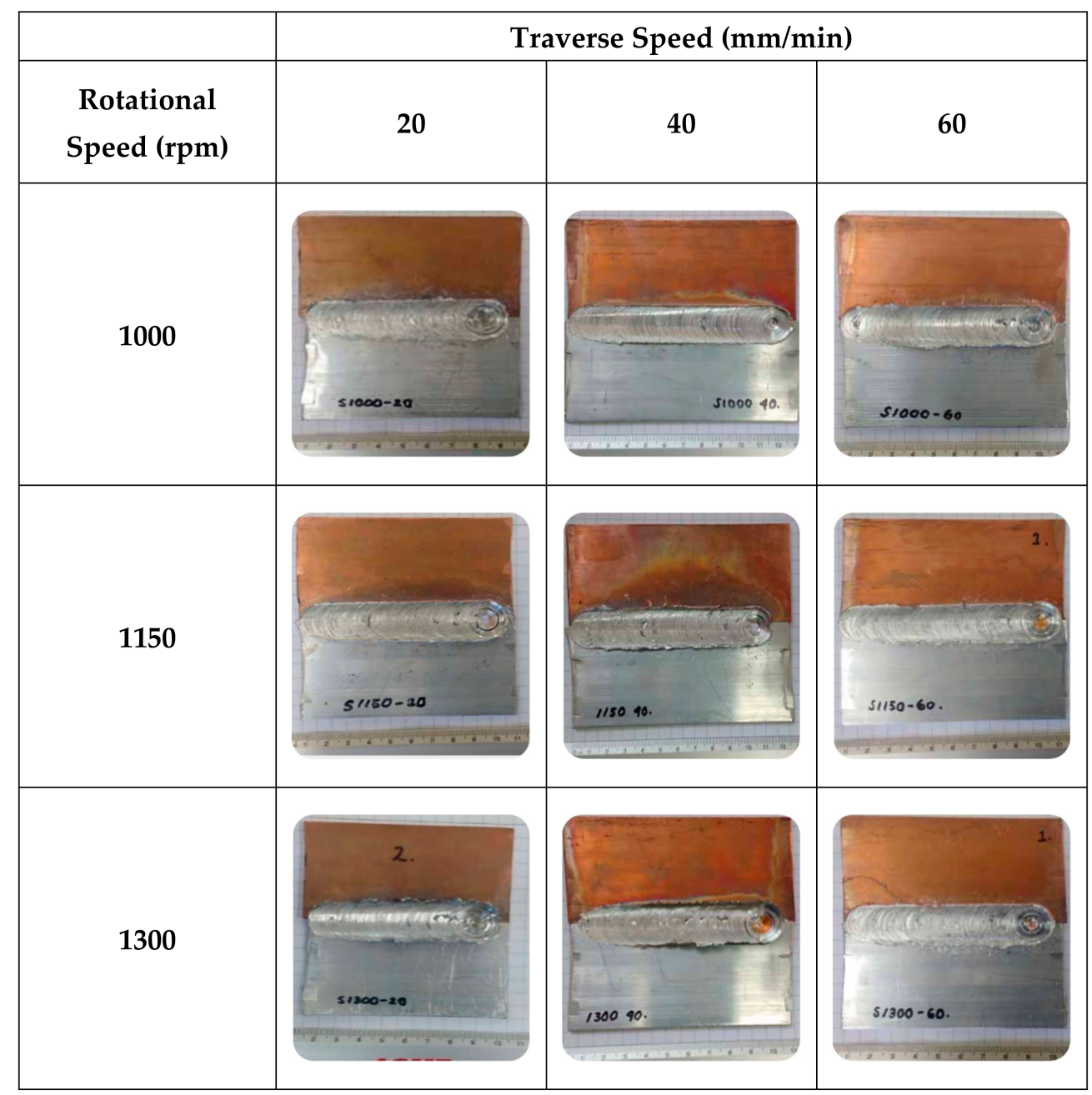

Figure 2. Upper surface of Al-Cu joints with different combinations of FSW parameters.

\subsection{Potentiodynamic Test}

The corrosion rate for each base material was determined from the potentiodynamic curves (Figure 4): 1.104 mpy for $\mathrm{Al}$ 6061-T6 and 1.364 mpy for $\mathrm{Cu} \mathrm{C11000.} \mathrm{These} \mathrm{results} \mathrm{in-}$ dicate that $\mathrm{Al}$ 6061-T6 has greater corrosion resistance than $\mathrm{Cu} \mathrm{C} 11000$ when both materials are exposed to a $\mathrm{NaCl}$ solution. When aluminum comes into contact with an electrolyte, it first forms a compact and amorphous layer of aluminum oxide, mainly $\gamma-\mathrm{Al}_{2} \mathrm{O}_{3}$ (boehmite), a few nanometers thick. This layer will form at any temperature as soon as the solid metal touches an oxidizing medium. Covering the barrier layer is a thicker, less compacted and more porous outer layer of hydrated oxide. This second layer grows on the first following a reaction with the external environment (probably due to hydration), and its final thickness depends on the presence of physicochemical conditions (relative humidity and temperature) that favor the growth of the film [44,45].

The reactions that occur within the passive film when in contact with moisture or water are as follows:

$$
\begin{gathered}
\mathrm{Al}^{+3}+3 \mathrm{OH}^{-} \rightarrow \mathrm{AlOOH}+\mathrm{H}_{2} \mathrm{O} \\
\mathrm{Al}_{2} \mathrm{O}_{3}+\mathrm{H}_{2} \mathrm{O} \rightarrow 2 \mathrm{AlOOH} \\
\mathrm{AlOOH}+\mathrm{H}_{2} \mathrm{O} \rightarrow \mathrm{Al}(\mathrm{OH})_{3}
\end{gathered}
$$




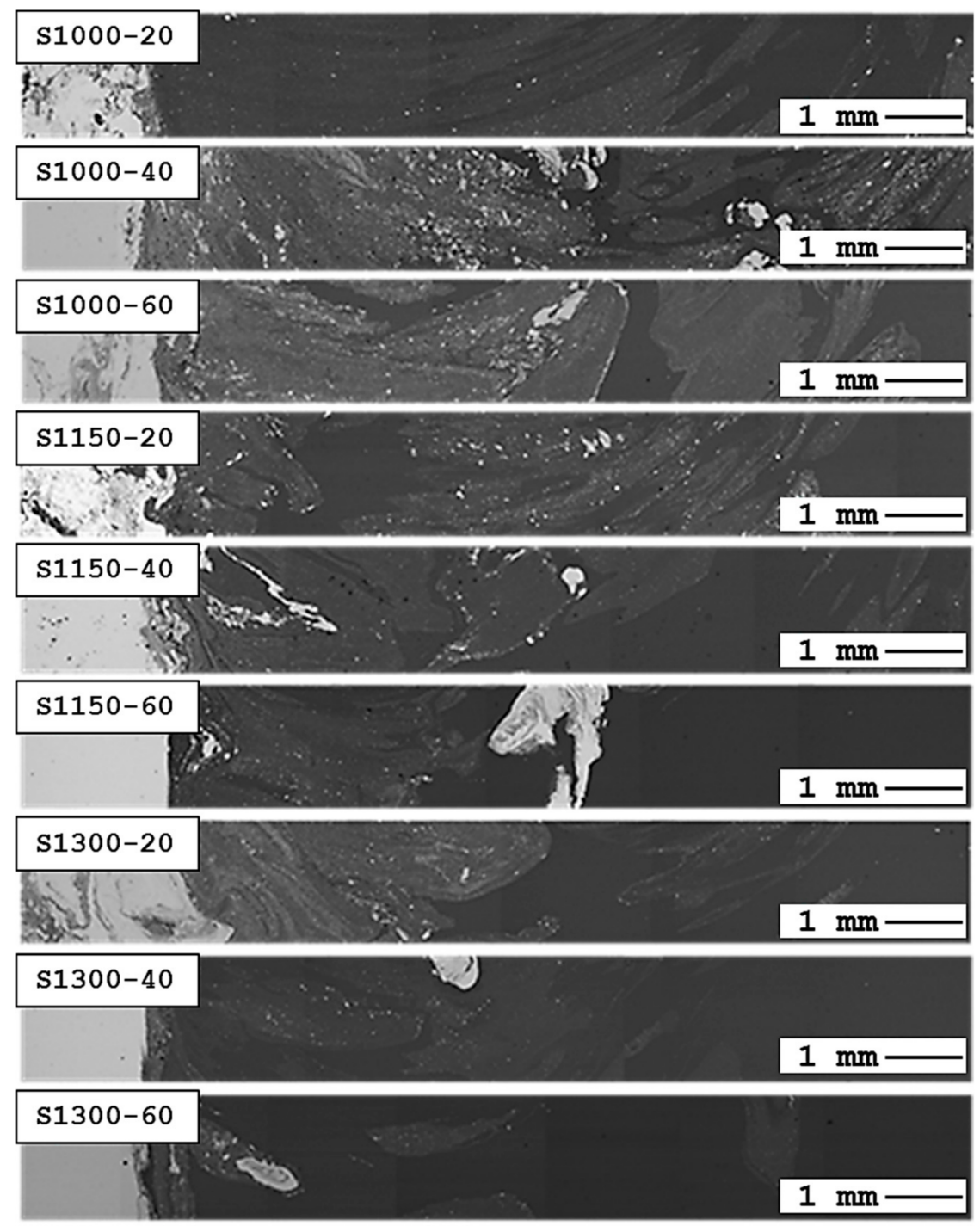

Figure 3. Scanning electron microscopy (SEM) macro-sections at $50 \times$ magnification of the upper surfaces of all the samples of Al 6061-T6-Cu C11000 under different FSW conditions.

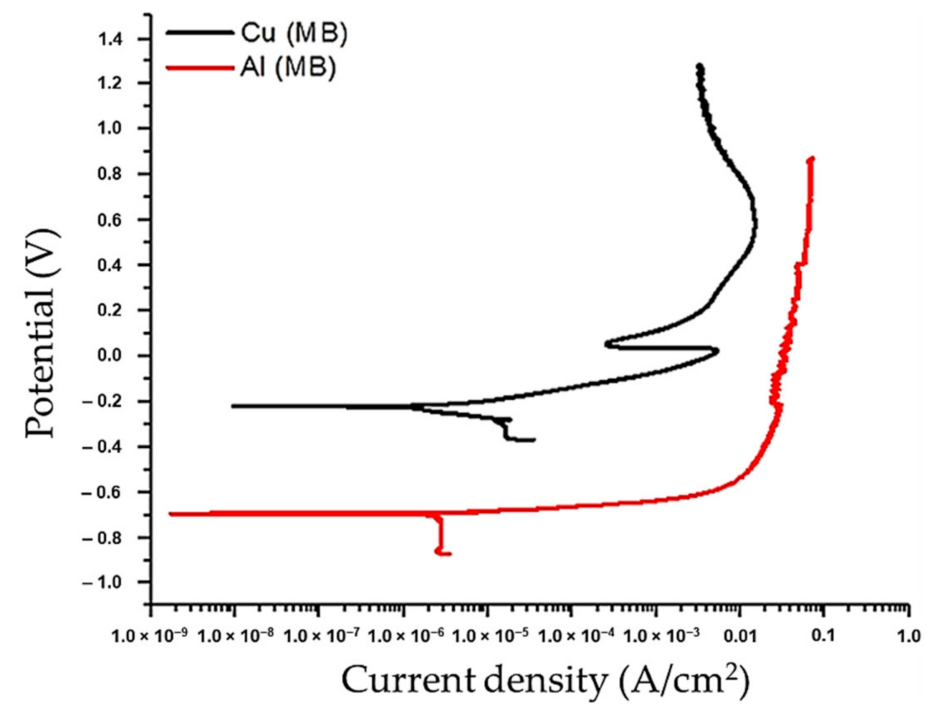

Figure 4. Potentiodynamic curves of base materials. 
According to Volkan [45], the composition of the outer layer is a mixture of $\mathrm{Al}_{2} \mathrm{O}_{3}$ and hydrated $\mathrm{Al}_{2} \mathrm{O}_{3}$, mainly in the form of amorphous $\mathrm{Al}(\mathrm{OH})_{3}$ or $\alpha-\mathrm{Al}(\mathrm{OH})_{3}$ (bayerite). This $\mathrm{AlOOH}-\mathrm{Al}(\mathrm{OH})_{3}$ outer coating is colloidal and porous, with poor corrosion resistance and cohesive properties. On the other hand, the inner layer is composed mainly of $\mathrm{Al}_{2} \mathrm{O}_{3}$ and small amounts of hydrated aluminum oxide, mainly in the form of $\mathrm{AlOOH}$ (boehmite). This internal $\mathrm{Al}_{2} \mathrm{O}_{3}-\mathrm{AlOOH}$ coating is continuous and corrosion resistant [44]. Goh [46] reported that with copper, the formation of $\mathrm{CuCl}_{2}$ does not allow the $\mathrm{Cu}$ 's self-passivation, and this will inevitably increase the rate of corrosion of $\mathrm{Cu}$. Moreover, $\mathrm{Cl}^{-}$ions can act as a catalyst for copper corrosion and weaken or dissolve the stable passivation of the oxide film.

Figure 5 a presents the potentiodynamic curves of the weld zones obtained at $1300 \mathrm{rpm}$ and a range of traverse speeds, and Figure $5 \mathrm{~b}$ shows the weld zones obtained at $20 \mathrm{~mm} / \mathrm{min}$ and different rotational speeds. In both cases, a similar behavior to that of the Al 6061-T6 is obtained, as can be seen in Figure 5. This is because, during the FSW, the rotary tool was completely immersed in the aluminum plate, and it only touched the surface of the copper plate. The corrosion potential ranged from 677.63 to $700.53 \mathrm{mV}$, which is probably due to the quantity and size of the copper particles dragged onto the weld surface by the rotary tool. The copper particles and aluminum matrix form a galvanic couple, and since aluminum is less noble than copper, it will tend to corrode before copper.

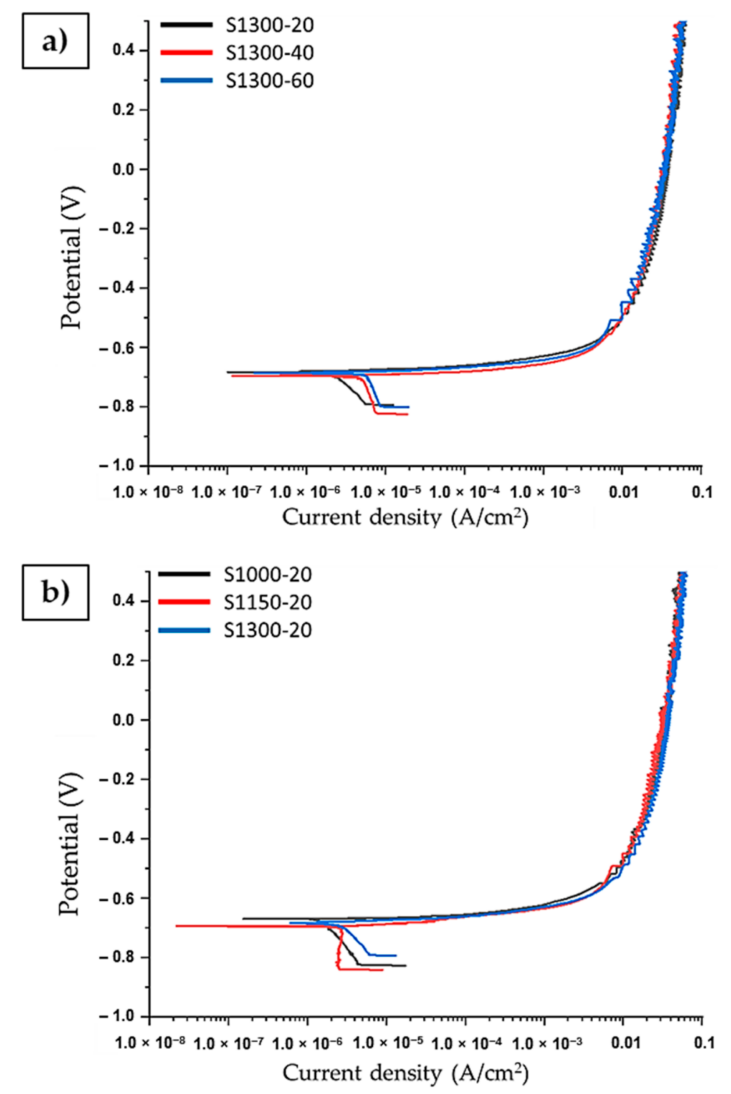

Figure 5. Potentiodynamic curves of FSW Al $6061 \mathrm{~T} 6-\mathrm{Cu}$ C11000 joints at (a) $1300 \mathrm{rpm}$ and different traverse speeds, and (b) $20 \mathrm{~mm} / \mathrm{min}$ and different rotational speeds.

As Table 3 shows, the corrosion rate has a proportional relationship with both traverse and rotational speeds. At higher traverse speeds and a constant rotational speed, the corrosion rate increases, while higher corrosion rates are obtained with higher rotational speeds and a constant traverse speed. The S1000-20 sample showed the lowest corrosion rate (0.95927 mpy), while the $51300-60$ sample presented the highest corrosion rate, at around $3.451 \mathrm{mpy}$. 
Table 3. Average values of corrosion rates in mpy for samples under different FSW conditions.

\begin{tabular}{cccc}
\hline $\begin{array}{c}\text { FSW } \\
\text { Parameters }\end{array}$ & $20 \frac{\mathrm{mm}}{\mathrm{min}}$ & $40 \frac{\mathrm{mm}}{\mathrm{min}}$ & $60 \frac{\mathrm{mm}}{\mathrm{min}}$ \\
\hline $1000 \mathrm{rpm}$ & 0.95927 & 1.68077 & 2.70767 \\
$1150 \mathrm{rpm}$ & 1.41167 & 2.57400 & 3.01230 \\
$1300 \mathrm{rpm}$ & 1.62900 & 3.36333 & 3.45100 \\
\hline
\end{tabular}

Figure 6 shows the microstructures of samples S1000-20 and S1300-60 after the corrosion tests. The weld zone's microstructure contains equiaxed grains with copper particles at the grain boundaries. As the tool was completely inserted into the aluminum side and only had surface contact with the copper side, detachment occurred due to the heat input effect and the material flow. Stirring and plastic deformation caused the disintegration of the detached copper into small particles, which were located at the grain boundaries during the recrystallization of the weld zone.

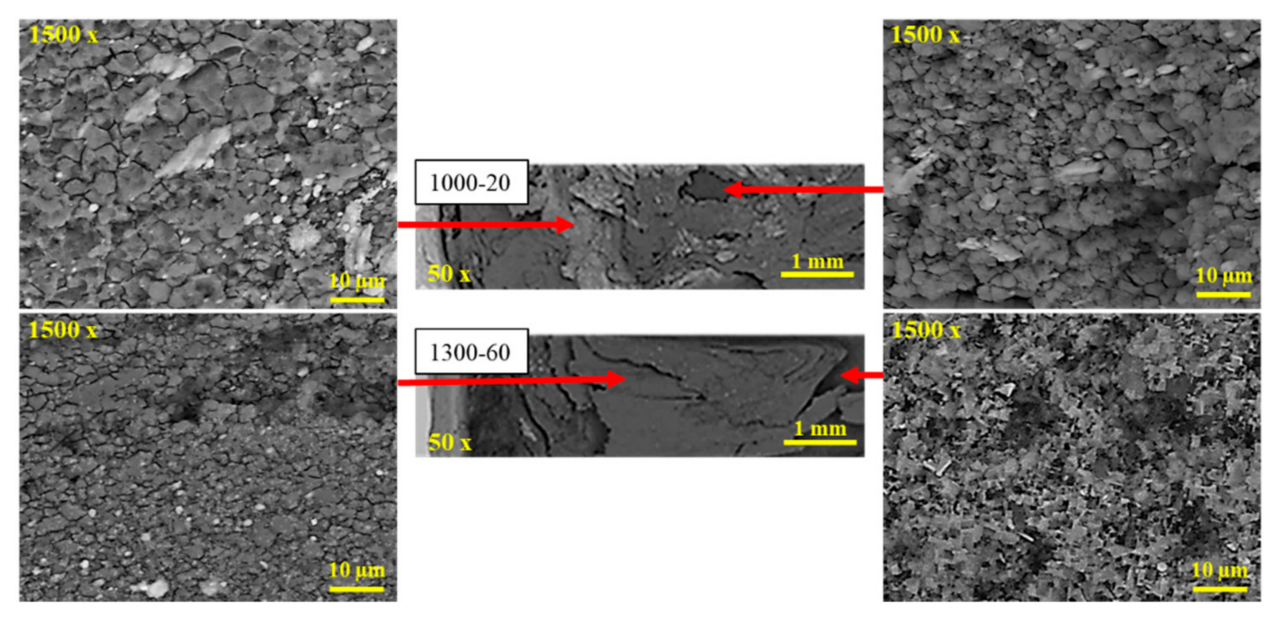

Figure 6. SEM micrographs of the upper surface weld zone, showing the intergranular corrosion of samples 1000-20 and 1300-60.

$\mathrm{NaCl}$ was seen to preferentially attack the grain boundaries of aluminum, while the copper particles were subjected to no visible attacks, because copper acts as a cathode in the galvanic microcell that is formed between the copper and aluminum. In Al-Mg-Si alloys, $\mathrm{Mg}$-Si particle precipitation occurs at the grain boundaries, which thus act as preferential sites for the commencement of corrosion when the alloy is exposed to a saline medium. These particles tend to be highly anodic with respect to the matrix, and they favor the activity of the galvanic couple [47-50].

Figure 7 schematically represents the formation of a galvanic microcell between a copper particle and the grain boundaries of the aluminum alloy, which act as a cathode and an anode, respectively. The formation of these microcells favors the nucleation of pits, which gives rise to an intergranular attack within the aluminum alloy. In addition to copper particles, the IMCs that are formed during welding (previously reported by Garcia [16]) could also act as cathodes in the formation of these microcells.

Figure 8 shows the effects of different welding conditions on the corrosion rates of all the samples. Increases in the rotational and the transverse speeds evidently increase the corrosion rate, this being greater with a higher transverse speed.

The corrosion resistance of $\mathrm{Al}-\mathrm{Cu}$ welds depends on their ability to produce a uniform film of corrosion products. This film acts as a barrier between the electrolyte and the surface [51]. The film's uniformity improves its corrosion resistance, and depends on the distribution and size of the copper particles. Furthermore, the corrosion resistance also depends on the grain size in the weld zone. 

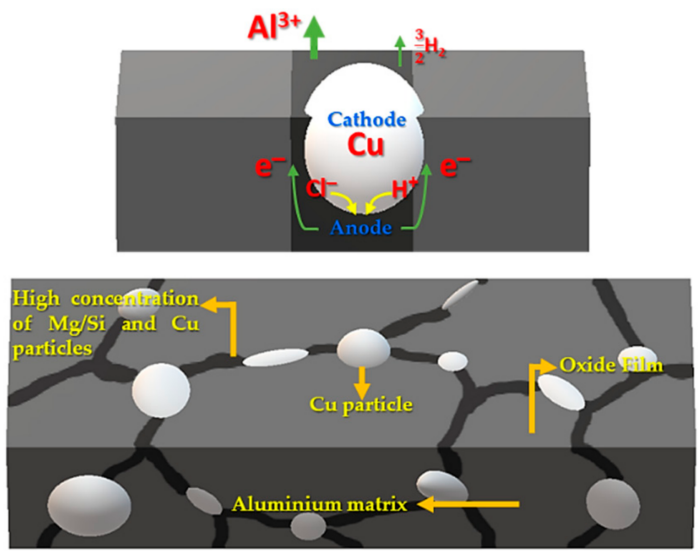

Figure 7. Schematic illustration of the intergranular corrosion mechanism in the weld zone.

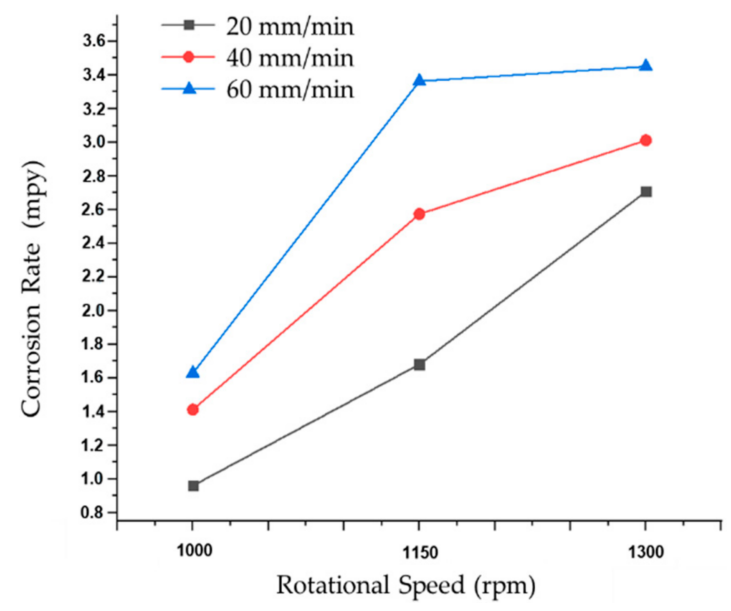

Figure 8. Effect of traverse and rotational speeds on the corrosion rates of all FSW Al 6061-T6-Cu C11000 joints.

Figure 9 shows the effects of the traverse and rotational speeds on the microstructure, the grain size, and the distribution and size of the copper particles, of the welds. The increases in the rotational and traverse speeds result in an increase in the copper particles' sizes. This increase is more noticeable for the traverse speed and is attributed to the rapid application of the heat source. Meanwhile, particle disintegration is not possible. In addition, the joint welded at $1000 \mathrm{rpm}$ shows a layered flow pattern, characteristic of FSW. However, as the rotational and traverse speeds increase, this pattern deforms as a consequence of the combination of high heat input and excessive stirring in the weld zone.

These microstructural differences cause zones wherein the large potential difference aids the localized attacking of the grain boundaries and the subsequent appearance of pits [52-54].

As the corrosion tests of the microstructures showed, the increases in rotational speed also caused an increase in the grain size as a consequence of the higher temperature during welding, which allowed grain growth during cooling. We can also see that a thickening of the anodic precipitates of Al-Mg-Si [55-57] increases the severity of the pitting. The increase in the traverse speed causes a reduction in the grain size due to the rapid movement of the heat source through the weld, which reduces the heat retention, thus limiting the recovery and grain growth [58]. Smaller grain sizes give rise to greater numbers of anodic sites, which aid in the formation of the galvanic couple, causing more significant surface attack [59]. 
(a)

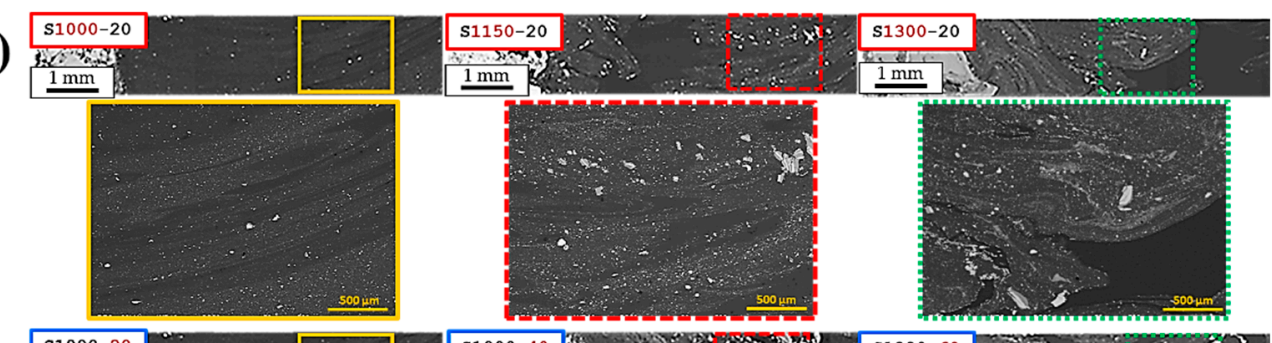

(b)
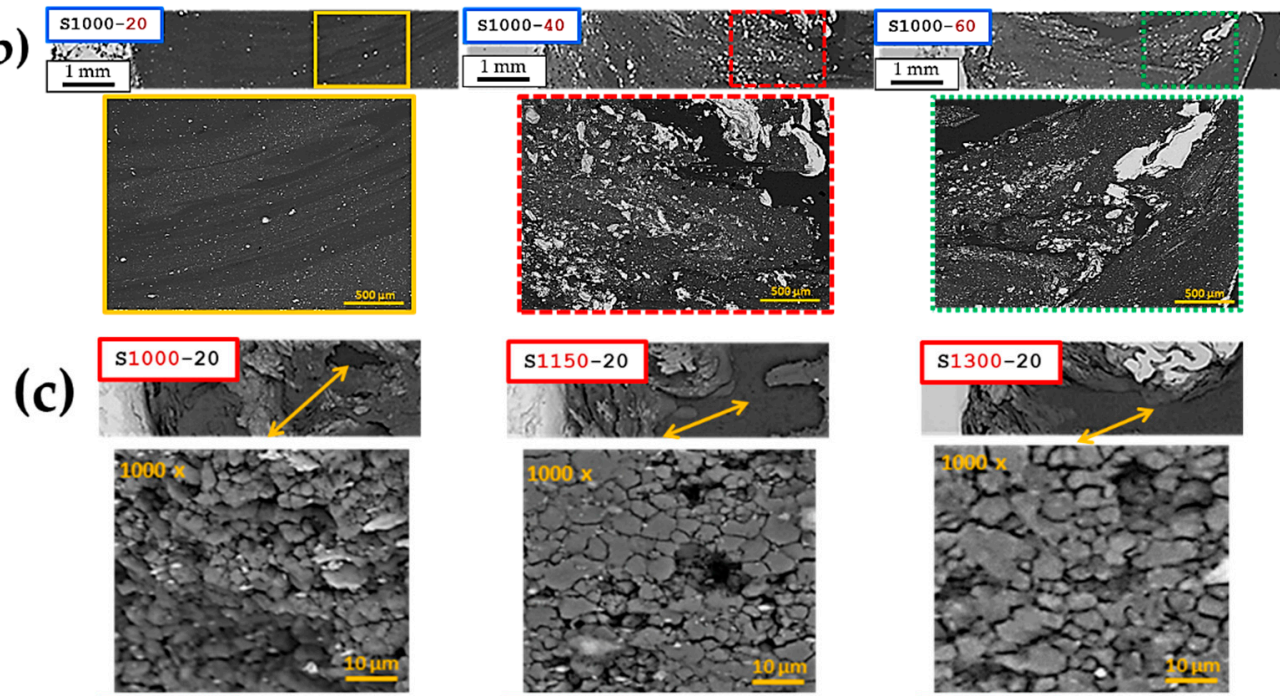

(d)
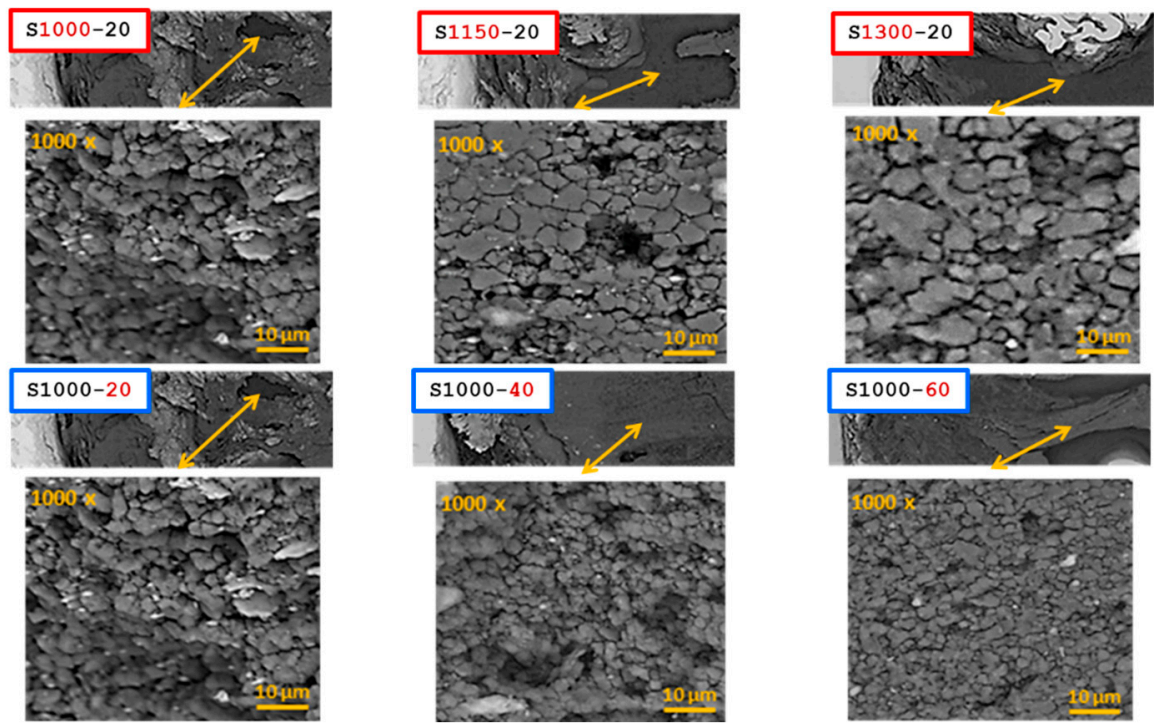

Figure 9. Effect of the of rotational and traverse speeds on the microstructure of the upper surface of the weld zones the welds, $(\mathbf{a}, \mathbf{c})$ variation of rotational speed, $(\mathbf{b}, \mathbf{d})$ variation of travel speed.

\subsection{Mathematical Model}

In order to develop the mathematical model, we performed three repetitions of each experiment, and the averages were determined. The model was proposed after 26 tests, and two tests were performed only for the $1300 \mathrm{rpm}$ and $60 \mathrm{~mm} / \mathrm{min}$ conditions. The standard deviation is one aspect of the mean of each test, which means that the experimental data oscillate close to the mean. The values of the standard deviation are $\mu \pm \sigma=68.27 \%$, $\mu \pm 2 \sigma=95.45 \%$ and $\mu \pm 3 \sigma=99.73 \%$.

The proposed model contains three degrees of freedom (dof), which are the rotational and the traverse speeds and the corrosion rate. However, it is important to consider a higher number of experiments than of dof, in order to ensure the robustness of the model. The least square method minimizes the distance between the obtained values and the proposed function, which allows the production of the curve that is most representative of the experimental values. The number of experimental repetitions (26) is higher than that of dof (3), and this is a sufficient condition to apply a mathematical model to the FSW process.

Once the average values from the corrosion rate data of the FSW process were obtained, as shown in Table 3, an analysis of variance (ANOVA) was proposed to demonstrate the effects of welding parameters on the corrosion rate. Besides this, a mathematical model is proposed to parametrize the effects of the rotational and traverse speeds on the corrosion rate in the FSW process, which is based on a powers equation enacted via the linearization 
of natural logarithms. Figure 10 shows the linear tendency between the percentile sample of each test and the corrosion rate. Therefore, a correlation study is made possible by the Pearson coefficient due to its simple implementation.

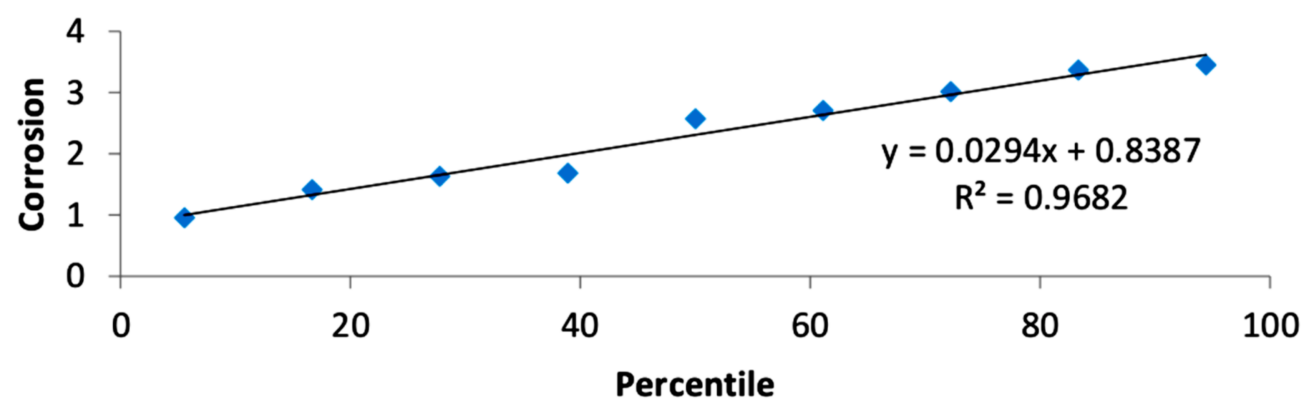

Figure 10. Normal probability distribution of corrosion resistance.

Moreover, Table 3 demonstrates the corrosion rate achieved under different welding conditions in mpy. Based on the normal probability calculations, a Pearson $(r)$ correlation study is undertaken to assess the FSW's practical implementation, and even to numerically indicate a linear relationship. The Pearson correlation should satisfy the following criteria:

$$
-1 \leq r \leq 1
$$

where the following obtains:

- $r>0 \mathrm{y}$ tends to increase when $\mathrm{x}$ increases;

- $r<0 \mathrm{y}$ tends to decrease when $\mathrm{x}$ increases.

Here, $x$ is the rotational and the traverse speeds variable, and $y$ is the corrosion rate. A strong linear relationship between $x$ and $y$ is guaranted when $r \rightarrow-1$ or $r \rightarrow 1$. The Pearson coefficient is computed as follows:

$$
r=\frac{S_{x y}}{S_{x} S_{y}}
$$

where $S_{x}$ and $S_{y}$ are the standard deviation from $x$ and $y$, respectively, and $S_{x y}$ is the covariance from $x$ and $y$. As such, the Pearson correlation determines the relationship between both variables. Table 4 shows compares the rotational and traverse speeds, using a Pearson correlation matrix, following a corrosion resistance test.

Table 4. Pearson correlation matrix.

\begin{tabular}{cccc}
\hline Variables & Rotational Speed & Traverse Speed & Corrosion \\
\hline Rotational speed & 0.95927 & 1.68077 & 2.70767 \\
Traverse speed & 1.41167 & 2.57400 & 3.01230 \\
Corrosion & 1.62900 & 3.36333 & 3.45100 \\
\hline
\end{tabular}

Table 5 describes the types of relationship between the variables and the correlation matrices.

Table 5. Type and degree of relationship between the variables in the FSW process.

\begin{tabular}{ccc}
\hline Variables & Relationship & Increase \\
\hline rotational speed-traverse speed & null & non-existent \\
corrosion-rotational speed & weak & positive \\
corrosion-traverse speed & significant & positive \\
\hline
\end{tabular}


The significance level is the probability of being able to reject the null hypothesis when it is true. As such, the significance levels represent the probability that the confidence interval of a distribution is beyond it. The above-mentioned suggests that the contrast statistic is in the rejection zone. The significance level $\alpha$ complements the confidence interval. As an example, if a $95 \%$ reliability study is done, then $\alpha=0.05$. In another example, if a 99\% reliability study is done, then $\alpha=0.01$.

Table 4 shows the experimental design employed to obtain a direct relationship between the corrosion rate and the different welding parameters, where the significance level of the variables for each experimental design is $\alpha=0.05$.

As such, it is important to establish the next hypothesis for the significance level $(\alpha)$, as follows. The null hypothesis: $H_{0}$ determines that there are no significant differences in the phenomena produced by the variables. The condition is the following, in which $\mathrm{F}$ is the statistical Fisher distribution and is defined as the difference in the variances of sampling distribution $S_{1}^{2}-S_{2}^{2}$ :

$$
F_{\text {computed }}<F_{\text {critical }}
$$

Therefore, the probability is greater than the level of significance $(\alpha)$.

The alternative hypothesis: $H_{1}$ determines that there are significant differences in the phenomena produced by the variables. The condition is the following:

$$
F_{\text {critical }} \geq F_{\text {computed }}
$$

Thus, the probability is lower than the level of significance $(\alpha)$.

Fisher distribution concerns the statistical factor $S_{1}^{2} / S_{2}^{2}$, which indicates the relationship among the variances. When this statistical factor is close to 1 , it describes a small variation between the samples. When the sample sizes $N_{1}$ and $N_{2}$ are equal to 2 , the normal variances $\sigma_{1}^{2}$ and $\sigma_{2}^{2}$ define the statistical factor $\mathrm{F}$, as follows:

$$
F=\frac{\frac{S_{1}^{2}}{\sigma_{1}^{2}}}{\frac{S_{2}^{2}}{\sigma_{2}^{2}}}
$$

and

$$
\hat{S}_{n}^{2}=\frac{N_{n} S_{n}^{2}}{N_{n}-1}
$$

The statistical Fisher distribution is

$$
F=\frac{C F^{\left(\frac{v_{1}}{2}\right)-1}}{\left(v_{1} F+v_{2}\right)^{\left(v_{1}+v_{2}\right) / 2}}
$$

where $C$ is a constant that depends on $v_{1}$ and $v_{2}$, such that the area under the curve is equal. The database tables in [60] are of note, wherein the distribution $v_{1}$ is the dof in the numerator from $V_{R}$ and $V_{C}$, and $v_{2}$ is the dof in the numerator $V_{E}$.

The variation between the treatments is as follows:

$$
V_{R}=b \sum_{i=1}^{a}\left(\bar{X}_{i}-\overline{\bar{X}}_{T}\right)^{2}
$$

where $a$ is the number of rows, $b$ is the number of columns, $x_{i, j}$ are the values on the table, $\bar{X}_{i}$ is the row average, $\bar{X}_{j}$ is the column average, and $\overline{\bar{X}}_{T}$ is the total average. The variation between the blocks is

$$
V_{C}=a \sum_{i=1}^{b}\left(\bar{X}_{j}-\overline{\bar{X}}_{T}\right)^{2}
$$


while the total variation is

$$
V=a \sum\left(\bar{X}_{i, j}-\overline{\bar{X}}_{T}\right)^{2}
$$

and the residual variation $V_{E}$ is

$$
V_{E}=V-V_{R}-V_{C}
$$

where $V$ is the total variation, $V_{R}$ is the variation between the treatments and $V_{C}$ is the variation between the blocks.

The mean square term between the treatments is

$$
S_{R}^{2}=\frac{V_{R}}{a-1}
$$

while the mean square term between blocks is

$$
S_{C}^{2}=\frac{V_{C}}{b-1}
$$

and the mean square term between residuals is

$$
S_{E}^{2}=\frac{V_{E}}{(a-1)(b-1)}
$$

In addition, the term $F_{\text {computed }}$ in the hypotheses $H_{0}$ and $H_{1}$ at (6) and (7) is determined by

$$
F_{\text {Rcomputed }}=\frac{S_{R}^{2}}{S_{E}^{2}}
$$

where $F_{\text {Rcomputed }}$ is related to the rotational speed, and

$$
F_{\text {Tcomputed }}=\frac{S_{C}^{2}}{S_{E}^{2}}
$$

where $F_{\text {Tcomputed }}$ is related to the traverse speed.

According to Tables 6 and 7 , the alternative hypothesis $H_{1}$ is validated for the welding parameters. Thus, the statistical analysis demonstrates the effects of the rotational and traverse speeds on the corrosion resistance. Here, dof is the number of degrees of freedom in the mathematical model.

Table 6. Two-factor analysis of variance.

\begin{tabular}{cccc}
\hline Variation Terms & dof & Quadratic Term & F \\
\hline$V_{R}$ & $a-1$ & $S_{R}^{2}$ & $S_{R}^{2} / S_{E}^{2}$ \\
$V_{C}$ & $b-1$ & $S_{C}^{2}$ & $S_{c}^{2} / S_{E}^{2}$ \\
$V_{E}$ & $(a-1)(b-1)$ & $S_{E}^{2}$ & \\
$V$ & $a b-1$ & & \\
\hline
\end{tabular}

Moreover, as regards the ANOVA study, a strategy to obtain an approximation function from the data, by minimizing the sum of the residual errors of all the available data between the experimentally measured " $y$ " and the computed " $y$ ", is expressed as follows:

$$
S_{r}=\sum_{i}^{n} e_{i}^{2}=\left(y_{i, \text { measured }}-y_{i, \text { computed }}\right)^{2}
$$


Table 7. Results of the two-factor analysis.

\begin{tabular}{ccccccc}
\hline Variable & Quadratic Sum & dof & Mean Quadratic & $\boldsymbol{F}$ & Probability & Crit. $\boldsymbol{F}$ \\
\hline Rotational speed & 1.59949 & 2 & 0.79975 & 9.67707 & 0.02934 & 6.94427 \\
Traverse speed & 4.69357 & 2 & 2.34678 & 28.39655 & 0.00433 & 6.94427 \\
Error & 0.33057 & 4 & 0.08264 & & & \\
Total & 6.62365 & 8 & & & & \\
\hline
\end{tabular}

Applying the concept of the quadratic error, a regression model is proposed based on a power equation that is linearized by natural logarithms. Here, $C$ is the corrosion (mpy), $R$ is the rotational speed (rpm) and $v$ is the traverse speed $(\mathrm{mm} / \mathrm{min})$.

$$
C=a_{0} R^{a_{1}} v^{a_{2}}
$$

From the natural logarithm's properties, it is possible to linearize (21) as follows:

$$
\ln (C)=\ln \left(a_{0}\right)+a_{1} \ln (R)+a_{2} \ln (v)
$$

Then, applying the quadratic error Equation (20) to (22),

$$
S_{r}=\sum_{i}^{n}\left(\ln \left(C_{i}\right)-\ln \left(a_{0}\right)-a_{1} \ln \left(R_{i}\right)+a_{2} \ln \left(v_{i}\right)\right)^{2}=0
$$

To determine the values of the coefficients $a_{0}, a_{1}$ and $a_{2}$, it is necessary to find the partial derivative of (23) with respect to the coefficients $\partial S_{r} / \partial a_{0}, \partial S_{r} / \partial a_{1}$, and $\partial S_{r} / \partial a_{2}$, which are equal to zero. This minimizes the error between the measured data and the function-computed data. The mathematical model is

$$
C=e^{-15.240} R^{1.870} v^{0.787}
$$

and the magnitude of the residual error associated to the dependent variable is

$$
S_{t}=\sum_{i}^{n} e_{i}^{2}=\left(y_{i, \text { measured }}-y_{i, \text { average }}\right)
$$

$S_{t}$ represents the sum of the squares, which gives the average for the dependent variable y. The difference between $S_{t}$ and $S_{r}$ quantifies the reduction in the error by describing the data in terms of a linear function instead of an average value. The difference is normalized in terms of $S_{t}$ to obtain

$$
r^{2}=\frac{S_{t}-S_{r}}{S_{t}}
$$

where $r^{2}$ is the determination coefficient and $r$ is the correlation coefficient. In the ideal case, $S_{r}=0$ and $r=r^{2}=1$, and this would explain $100 \%$ of the data variability. On the contrary, when $S_{t}=S_{r}$ and $r=r^{2}=0$, the adjustment does not offer any improvement. The standard error is formulated as follows:

$$
S_{\frac{y}{x}}=\sqrt{\frac{S_{r}}{n-(m+1)}}
$$

where $n$ and $m$ are used to obtain the coefficients $a_{0}, a_{1}$ and $a_{2}$ in (21). Similarly, $m+1$ is the total dof, and $n$ is the number of experiments. Therefore, to compute the $r_{\text {adjusted }}^{2}$, the following equation is used:

$$
r_{\text {adjusted }}^{2}=1-\frac{n-1}{n-(m+1)}\left(1-r^{2}\right)
$$


the determination-adjusted coefficient is used to validate the degree of effectiveness of the independent variables.

Table 8 shows the results of the statistical analysis, wherein there is a direct relationship between the welding parameters and the corrosion resistance, based on the factor $r$. Furthermore, the corrosion resistance has a high variability as a function of the welding parameters, as is demonstrated by the factor $r^{2}$. The adjusted $r_{\text {adjusted }}^{2}$ indicates the significant influence of the input variables over the model. Finally, the error is considered too low to affect the relationship of the experimental data with the proposed model.

Table 8. Statistical analysis results.

\begin{tabular}{cc}
\hline Variables & Value \\
\hline$r$ & 0.94554 \\
$r^{2}$ & 0.89404 \\
$r_{\text {adjusted }}^{2}$ & 0.85872 \\
error & 0.34201 \\
Observations $n$ & 9 \\
\hline
\end{tabular}

Figure 11 compares the experimental results and the estimated model related to the effects of the welding parameters on the corrosion rate. The model has a low absolute percentage error, and, therefore, can be utilized to obtain reliable results.

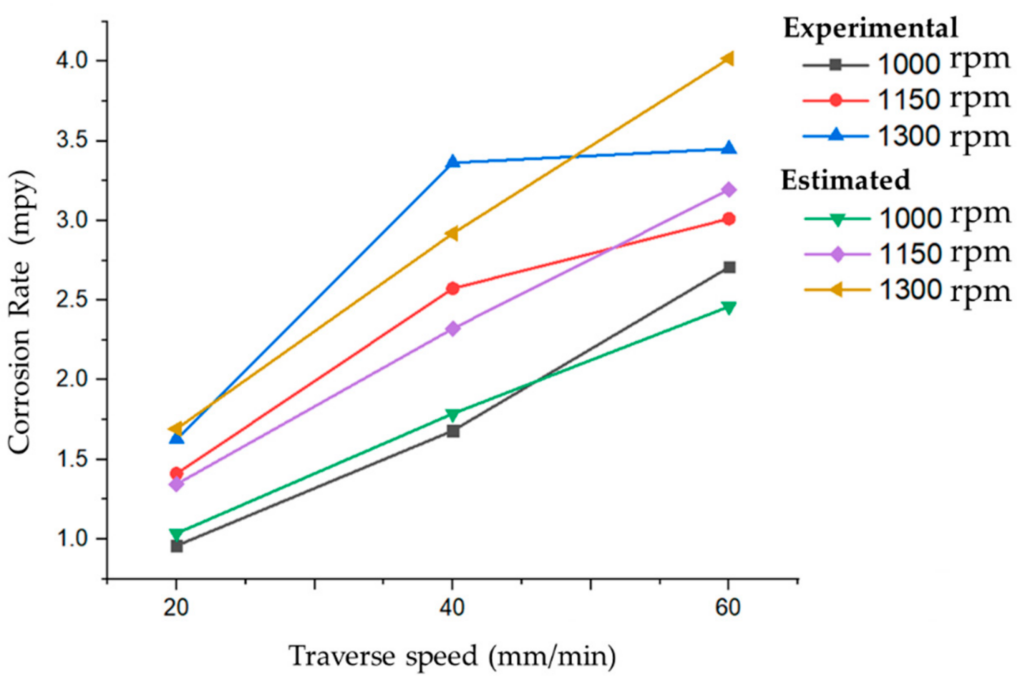

Figure 11. Comparison between the experimental results and the estimated model concerning the effect of the welding parameters on the corrosion rate.

According to the color scale in Figure 12, a traverse speed between 20 and $30 \mathrm{~mm} / \mathrm{min}$ causes a small change in corrosion rate. On the other hand, a traverse speed of $20 \mathrm{~mm} / \mathrm{min}$ causes greater interaction between both materials, resulting in a mixture with a larger grain size, as is shown in Figures 3 and 6. Similar results in Al-Cu bonds have been reported by Akinlabi et al. [61] and Rojanapanya et al. [62], who, respectively, recommend working with traverse speeds between 20 and $50 \mathrm{~mm} / \mathrm{min}$ in order to ensure metallurgical joints free of defects. 


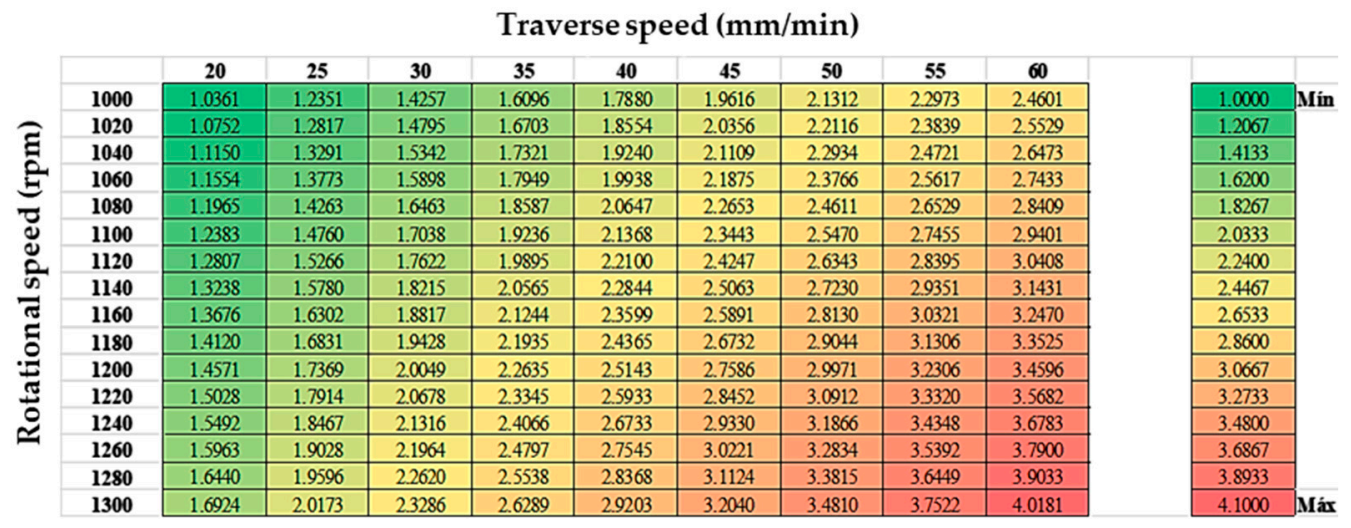

Figure 12. Surface simulation of the rotational and traverse speeds' impacts on the corrosion rate, via the mathematical model.

The statistical model helps quantify the effects of the rotational and traverse speeds on the corrosion rate. In addition, the statistical model avoids the need for many experiments, as the effectiveness value of the model has been variously shown to be $85 \%$ and $89.4 \%$ in terms of uncertainty.

\section{Conclusions}

- Dissimilar welds of Al 6061-T6 and C11000 plates were obtained via friction stir welding in a conventional milling machine at different rotational and traverse speeds. The lowest quantity of defects was found in welds obtained at 1000 and $1150 \mathrm{rpm}$, with a traverse speed of 20 and $40 \mathrm{~mm} / \mathrm{min}$.

- The lowest corrosion rate was obtained for the sample S1000-20, at $0.95924 \mathrm{mpy}$, while the sample S1300-60 obtained the highest corrosion rate of $3.45 \mathrm{mpy}$. As regards specific applications, the presented results establish the appropriate conditions for the FSW process.

- The implementation of statistical tools in this work allowed the parameterization of the FSW process, incorporating better control a higher quality of the product in the manufacturing processes. In addition, it effectively simulated the effects on the corrosion rate under different welding parameters of interest.

- Via ANOVA and the proposed model's equations, it is possible to quantify the relationship between the rotational and traverse speeds. The ANOVA study establishes that the degree of relationship between the input and output variables in the FSW process is high, while the model establishes an equation for analyzing the FSW, as regards the effect of the welding parameters on corrosion resistance, without resorting to excessive experimentation.

- The statistical analysis demonstrates a significant relationship between the rotational and traverse speeds and the corrosion resistance. Moreover, the mathematical analysis validates the experimentally determined effects of the processing parameters employed during the FSW process.

- It is concluded that the analysis of variance assessed in each group of experiments supports the results obtained through the correlation analysis.

- With the obtained results, we can conclude that the model for designing the FSW process is statistically acceptable. The correlation coefficient $r$ shows a strong relationship between the input (welding parameters) and output (corrosion rate) variables, with $94.554 \%$ correlation achieved in each group of tests

- With the obtained results, we can conclude that the model for designing the FSW process is statistically acceptable. The correlation coefficient $r$ shows a strong relationship between the input (welding parameters) and output (corrosion rate) variables, with $94.554 \%$ correlation achieved in each group of tests 
- The factor $r^{2}$ shows the significant influence of the input variables (rotational and traverse speeds) over the model. The $r^{2}$ value of the corrosion resistance explains a significant percentage $(89.404 \%)$ of the variability in the data, and thus the uncertainty of the phenomenon

- The standard error is low, which means that each value estimated with the model will have an error of $\pm 0.34201 \mathrm{mpy}$.

Author Contributions: Conceptualization, N.A.R.-R., and F.A.M.-G.; methodology, N.A.R.-R. and C.R.M.-V.; validation, J.S.G.-V. and J.C.O.-C.; formal analysis, J.G.-C. and O.G.-C.; investigation, F.A.M.-G. and N.A.R.-R.; resources, C.R.M.-V.; data curation, J.G.-C.; writing-original draft preparation, J.G.-C., N.A.R.-R. and F.A.M.-G.; software, J.G.-C. and O.G.-C.; writing-review and editing, J.S.G.-V. and C.R.M.-V.; supervision, J.G.-C. All authors have read and agreed to the published version of the manuscript.

Funding: This research received no external funding.

Data Availability Statement: The data and methods used in the research are presented in sufficient detail in the document for other researchers to replicate the work.

Acknowledgments: We gratefully acknowledge CONACYT México, Tecnológico Nacional de México and Universidad Autónoma de Coahuila for the support in this investigation.

Conflicts of Interest: The authors declare no conflict of interest.

\section{References}

1. Ramamoorthi, R.; Yuvaraj, K.; Gokul, C.; Eashwar, S.; Arunkumar, N.; Dheen, S.A.T. An investigation of the impact of axial force on friction stir-welded AA5086/AA6063 on microstructure and mechanical properties butt joints. Mater. Today Proc. 2020, 37, 3159-3163. [CrossRef]

2. Gotawala, N.; Shrivastava, A. Analysis of material distribution in dissimilar friction stir welded joints of Al 1050 and copper. $J$. Manuf. Process. 2020, 57, 725-736. [CrossRef]

3. Sen, M.; Chattopadhyaya, S. Investigations into FSW joints of dissimilar aluminum alloys. Mater. Today Proc. 2020, 27, $2455-2462$. [CrossRef]

4. Hou, W.; Shah, L.H.A.; Huang, G.; Shen, Y.; Gerlich, A. The role of tool offset on the microstructure and mechanical properties of $\mathrm{Al} / \mathrm{Cu}$ friction stir welded joints. J. Alloys Compd. 2020, 825, 154045. [CrossRef]

5. Prabhu, L.; Kumar, S.S. Tribological characteristics of FSW tool subjected to joining of dissimilar AA6061-T6 and Cu alloys. Mater. Today Proc. 2020, 33, 741-745. [CrossRef]

6. Sezhian, M.V.; Ramadoss, R.; Giridharan, K.; Chakravarthi, G.; Stalin, B. Comparative study of friction stir welding process and its variables. Mater. Today Proc. 2020, 33, 4842-4847.

7. Guan, Q.; Zhang, H.; Liu, H.; Gao, Q.; Gong, M.; Qu, F. Structure-property characteristics of Al-Cu joint formed by highrotation-speed friction stir lap welding without tool penetration into lower Cu sheet. J. Manuf. Process. 2020, 57, 363-369. [CrossRef]

8. Ramesh, N.; Kumar, V.S. Experimental Erosion-Corrosion Analysis of Friction Stir Welding of AA 5083 and AA 6061 for Sub-Sea applications. Appl. Ocean Res. 2020, 98, 102121. [CrossRef]

9. Shah, L.H.; Othman, N.H.; Gerlich, A. Review of research progress on aluminium-magnesium dissimilar friction stir welding. Sci. Technol. Weld. Join. 2017, 23, 256-270. [CrossRef]

10. Jagadeesha, C.B. FSW between Al alloy and Mg Alloy: The comparative study. J. Mech. Behav. Mater. 2017, 26, 25-42. [CrossRef]

11. Mingrun, Y.; Hongyun, Z.; Zhihua, J.; Zili, Z.; Fei, X.; Li, Z.; Xiaoguo, S. Influence of welding parameters on interface evolution and mechanical properties of FSW Al/Ti lap joints. Mater. Sci. Technol. 2019, 35, 1543-1554.

12. Zhou, L.; Yu, M.; Zhao, H.; Jiang, Z.; Guo, F.; Song, X. Dissimilar friction stir welding of AA6061 and Ti6Al4V alloys: A study on microstructure and mechanical properties. J. Manuf. Process. 2019, 48, 119-126. [CrossRef]

13. Safeen, M.W.; Russo Spena, P. Main Issues in Quality of Friction Stir Welding Joints of Aluminum Alloy and Steel Sheets. Metals 2019, 9, 610. [CrossRef]

14. Liu, F.C.; Dong, P. From thick intermetallic to nanoscale amorphous phase at Al-Fe joint interface: Roles of friction stir welding conditions. Scr. Mater. 2020, 191, 167-172. [CrossRef]

15. Sorger, G.; Wang, H.; Vilaça, P.; Santos, T.G. FSW of aluminum AA5754 to steel DX54 with innovative overlap joint. Weld World 2017, 61, 257-268. [CrossRef]

16. García-Navarro, D.; Ortiz-Cuellar, J.C.; Galindo-Valdés, J.S.; Gómez-Casas, J.; Muñiz-Valdez, C.R.; Rodríguez-Rosales, N.A. Effects of the FSW Parameters on Microstructure and Electrical Properties in Al 6061-T6- Cu C11000 Plate Joints. Crystals 2021, 11, 21. [CrossRef] 
17. Patel, N.P.; Parlikar, P.; Singh Dhari, R.; Mehta, K.; Pandya, M. Numerical modelling on cooling assisted friction stir welding of dissimilar Al-Cu joint. J. Manuf. Process. 2019, 47, 98-109. [CrossRef]

18. Amani, H.; Soltanieh, M. Intermetallic Phase Formation in Explosively Welded Al/Cu Bimetals. Metall. Mater. Trans. B 2016, 47, 2524-2534. [CrossRef]

19. Mehta, K.P.; Vishvesh, J.B. A Review on Dissimilar Friction Stir Welding of Copper to Aluminum: Process, Properties, and Variants. Mater. Manuf. Process 2016, 31, 233-254. [CrossRef]

20. Zhang, J.; Shen, Y.; Yao, X.; Xu, H.; Li, B. Investigation on dissimilar underwater friction stir lap welding of 6061-T6 aluminum alloy to pure copper. Mater. Des. 2014, 64, 74-80. [CrossRef]

21. Galvão, I.; Loureiro, A.; Oliveira, J.C.; Rodrigues, D. Formation and distribution of brittle structures in friction stir welding of aluminium and copper: Influence of shoulder geometry. Intermetallics 2012, 22, 122-128. [CrossRef]

22. Mehta, K.P.; Badheka, V.J. Effects of tilt angle on the properties of dissimilar friction stir welding copper to aluminum. Mater. Manuf. Process 2016, 31, 255-263. [CrossRef]

23. Safi, S.V.; Amirabadi, H.; Givi, M.K.B. Formation and distribution of brittle structures in friction stir welding of AA 6061 to copper. Influence of preheat. Mech. Mater. Sci. Eng. 2016. [CrossRef]

24. Mehta, K.P.; Badheka, V.J. Influence of tool design and process parameters on dissimilar friction stir welding of copper to AA6061-T651 joints. Int. J. Adv. Manuf. Technol. 2015, 80, 2073-2082. [CrossRef]

25. Shukla, R.K.; Shah, P.K. Investigation of joint properties of friction stir welding of aluminum 6061 alloy to copper. Int. J. Eng. Res. Technol. 2010, 3, 613-620.

26. Mehta, K.P.; Badheka, V.J. Hybrid approaches of assisted heating and cooling for friction stir welding of copper to aluminum joints. J. Mater. Process Technol. 2017, 239, 336-345. [CrossRef]

27. Akinlabi, E.T.; Andrews, A.; Akinlabi, S.A. Effects of processing parameters on corrosion properties of dissimilar friction stir welds of aluminium and copper. Trans. Nonferrous Met. Soc. China 2014, 24, 1323-1330. [CrossRef]

28. Venkata Rao, C.; Madhusudhan Reddy, G.; Srinivasa Rao, K. Microstructure and pitting corrosion resistance of AA2219 Al-Cu alloy friction stir welds-Effect of tool profile. Def. Technol. 2015, 11, 123-131. [CrossRef]

29. Naumov, A.; Isupov, F.; Rylkov, E.; Polyakov, P.; Panteleev, M.; Skupov, A.; Amancio-Filho, S.T.; Panchenko, O. Microstructural evolution and mechanical performance of Al-Cu-Li alloy joined by friction stir welding. J. Mater. Res. Technol. 2020, 9, 14454-14466. [CrossRef]

30. Lee, W.B.; Yeon, Y.M.; Jung, S.B. The joint properties of dissimilar formed Al alloys by friction stir welding according to the fixed location of materials. Scr. Mater. 2003, 49, 423-428. [CrossRef]

31. Mubiayi, M.P.; Akinlabi, E.T.; Makhatha, M.E. Current Trends in Friction Stir Welding (FSW) and Friction Stir Spot Welding (FSSW); Springer: Cham, Switzerland, 2019; pp. 17-65.

32. Yunus, M.; Alsoufi, M.S. Mathematical Modelling of a Friction Stir Welding Process to Predict the Joint Strength of Two Dissimilar Aluminium Alloys Using Experimental Data and Genetic Programming. Model. Simul. Eng. 2018. [CrossRef]

33. Prasad Rao, K.; Janaki Ram, G.D.; Stucker, B.E. Effect of friction stir processing on corrosion resistance of aluminum-copper alloy gas tungsten arc welds. Mater. Des. 2010, 31, 1576-1580. [CrossRef]

34. Prabhuraj, P.; Rajakumar, S. Experimental investigation on corrosion behavior of friction stir welded AA7075-T651 aluminium alloy under 3.5\% wt $\mathrm{NaCl}$ environment. Mater. Today Proc. 2020. [CrossRef]

35. Palanivel, R.; Mathews, P.K.; Murugan, N. Development of mathematical model to predict the mechanical properties of friction stir welded AA6351 aluminum alloy. J. Eng. Sci. Technol. Rev. 2011, 4, 25-31. [CrossRef]

36. Dubovikova, N.; Gerlach, E.; Zeidis, I.; Zimmermann, K. Mathematical modeling of friction stir welding considering dry and viscous friction. Appl. Math. Model. 2019, 67, 1-8.

37. Ighisan, C.; Radu, B.; Ciucă, C. Mathematical Modelling of Material Flow during Friction Stir Welding of Aluminium Alloys. Adv. Mater. Res. 2018, 1146, 115-120. [CrossRef]

38. Fotouhi, Y.; Rasaee, S.; Askari, A.; Bisadi, H. Effect of transverse speed of the tool on microstructure and mechanical properties in dissimilar butt friction stir welding of Al5083-copper sheets. Eng. Solid Mech. 2014, 2, 239-246. [CrossRef]

39. Tavassolimanesh, A.; Nia, A.A. A new approach for manufacturing copper-clad aluminum bimetallic tubes by friction stir welding (FSW). J. Manuf. Process. 2017, 30, 374-384. [CrossRef]

40. Khan, N.; Siddiquee, A.; Khan, Z. Friction Stir Welding: Dissimilar Aluminum Alloys; CRC Press: Boca Raton, FL, USA, 2017.

41. Akinlabi, E.T.; Els-Botes, A.; Mcgrath, P.J. Effect of travel speed on joint properties of dissimilar metal friction stir welds. In Proceedings of the 2nd International Conference on Advances in Engineering and Technology (AET), Entebbe, Uganda, 31 January-2 February 2011; pp. 155-161.

42. Muthu, M.; Jayabalan, V. Tool travel speed effects on the microstructure of friction stir welded aluminum-copper joints. J. Mater. Process. Technol. 2015, 217, 105-113. [CrossRef]

43. Kim, Y.; Fujii, H.; Tsumura, T.; Komazaki, T.; Nakata, K. Three defect types in friction stir welding of aluminum die casting alloy. Mater. Sci. Eng. A 2006, 415, 250-254. [CrossRef]

44. Davis, J.R. Corrosion of Aluminum and Aluminum Alloys; ASM International: Cleveland, OH, USA, 1999.

45. Volkan, C.; Al-Numan, B. Corrosion Chemistry; Wiley-Scrivener: Beverly, MA, USA, 2011.

46. Goh, C.S.; Chong, W.L.E.; Lee, T.K.; Breach, C. Corrosion study and intermetallics formation in gold and copper wire bonding in microelectronics packaging. Crystals 2013, 3, 391-404. [CrossRef] 
47. Ezuber, H.; El-Houd, A.; El-Shawesh, F. A study on the corrosion behavior of aluminum alloys in seawater. Mater. Des. 2008, 29, 801-805. [CrossRef]

48. Guillaumin, V.; Mankowski, G. Localized corrosion of 6056-T6 aluminium alloy in chloride media. Corros. Sci. 2000, 42, 105-125. [CrossRef]

49. Larsen, M.H.; Walmsley, J.C.; Lunder, O.; Nisancioglu, K. Effect of excess silicon and small copper content on intergranular corrosion of 6000 series aluminum alloys. J. Electrochem. Soc. 2010, 155, C61-C68. [CrossRef]

50. Andreatta, F.; Terryn, H.; De Wit, J.H. Effect of solution heat treatment on galvanic coupling between intermetallics and matrix in AA7075-T6. Corros. Sci. 2003, 45, 1733-1746. [CrossRef]

51. Zhou, P.; Deng, L.; Guo, P.; Rao, W.; Wang, X.; Zhang, M. Influence of Microstructure Heterogeneity on the Corrosion Resistance and Microhardness of 5052 Al-Mg Alloy. JOM 2020, 72, 4305-4314. [CrossRef]

52. Sharma, M.M.; Tomedi, J.D.; Parks, J.M. A microscopic study on the corrosion fatigue of ultra-fine grained and conventional Al-Mg alloy. Corros. Sci. 2015, 93, 180-190. [CrossRef]

53. Gollapudi, S. Grain size distribution effects on the corrosion behaviour of materials. Corros. Sci. 2012, 62, 90-94. [CrossRef]

54. Yan, Y.; Chu, X.; Luo, X.; Xu, X.; Zhang, Y.; Dai, Y.; Li, D.; Chen, L.; Xiao, T.; Yu, K. A homogenous microstructural Mg-based matrix model for orthopedic application with generating uniform and smooth corrosion product layer in Ringer's solution: Study on biodegradable behavior of Mg-Zn alloys prepared by powder metallurgy as a case. J. Magnes. Alloys 2021, 9, 225-240. [CrossRef]

55. Steuwer, A.; Dumont, M.; Altenkirch, J.; Birosca, S.; Deschamps, A.; Prangnell, P.B.; Withers, P.J. A combined approach to microstructure mapping of an Al-Li AA2199 friction stir weld. Acta Mater. 2011, 59, 3002-3011. [CrossRef]

56. Li, J.F.; Li, C.X.; Peng, Z.W.; Chen, W.J.; Zheng, Z.Q. Corrosion mechanism associated with T1 and T2 precipitates of Al-Cu-Li alloys in $\mathrm{NaCl}$ solution. J. Alloys Compd. 2008, 460, 688-693. [CrossRef]

57. Frøseth, A.G.; Høier, R.; Derlet, P.M.; Andersen, S.J.; Marioara, C.D. Bonding in mgsi and Al-Mg-Si compounds relevant to Al-Mg-Si alloys. Phys. Rev. B 2003, 67, 224106. [CrossRef]

58. Abnar, B.; Kazeminezhad, M.; Kokabi, A.H. Effects of heat input in friction stir welding on microstructure and mechanical properties of AA3003H18 plates. Trans. Nonferrous Met. Soc. China 2015, 25, 2147-2155. [CrossRef]

59. Birbilis Och, N.; Buchheit, R.G. Electrochemical characteristics of intermetallic phases in aluminum alloys an experimental survey and discussion. J. Electrochem. Soc. 2005, 152, B140-B151. [CrossRef]

60. Spiegel, M.R.; John, J.; Srinivasan, R. Probabilidad y Estadística/Murray, R. Spiegel, John J. Schiller y R. Alu Srinivasan; Technical Report; McGraw-Hill Interamericana: México City, México, 2013; p. 425.

61. Akinlabi, E.T.; Reddy, R.D.; Akinlabi, S.A. Microstructural characterizations of dissimilar friction stir welds. In Proceedings of the World Congress on Engineering (WCE), London, UK, 4-6 July 2012; pp. 4-6.

62. Rojanapanya, K.; Canyook, R.; Fakpan, K. Feasibility study of friction stir welding of dissimilar metals between 6063 aluminium alloy and pure copper. Naresuan. Univ. Eng. J. 2017, 12, 1-8. 